\title{
Histomorphometry of the Testes, Epididymides, and Spermatozoa of Four Indigenous Breeds of Bulls in Ibadan, Nigeria
}

\author{
Ayodeji Ayotunde Oni ${ }^{*}$, Matthew Olugbenga Oyeyemi², Joseph Atawalna ${ }^{3}$ \\ ${ }^{1}$ School of Veterinary Medicine, College of Basic and Applied Sciences, University of Ghana, Legon-Accra, Ghana \\ ${ }^{2}$ Department of Theriogenology, Faculty of Veterinary Medicine, University of Ibadan, Ibadan, Nigeria \\ ${ }^{3}$ School of Veterinary Medicine, Kwame Nkrumah University of Science and Technology, Kumasi, Ghana \\ Email: ^dejioni2000@yahoo.com
}

How to cite this paper: Oni, A.A., Oyeyemi, M.O. and Atawalna, J. (2021) Histomorphometry of the Testes, Epididymides, and Spermatozoa of Four Indigenous Breeds of Bulls in Ibadan, Nigeria. Open Journal of Veterinary Medicine, 11, 299-306.

https://doi.org/10.4236/ojvm.2021.119020

Received: June 27, 2021

Accepted: September 27, 2021

Published: September 30, 2021

Copyright $\odot 2021$ by author(s) and Scientific Research Publishing Inc. This work is licensed under the Creative Commons Attribution International License (CC BY 4.0).

http://creativecommons.org/licenses/by/4.0/ Open Access

\begin{abstract}
Forty testicles were used to carry out histomorphometry study on the testes, epididymides and spermatozoa of four indigenous breeds of bull found in Ibadan (Red Bororo (RB), Sokoto Gudali (SG), White Fulani (WF) and Dhali $(\mathrm{DL}))$. The testicles were harvested immediately after the slaughter at the Bodija abattoir and transported to the laboratory in an insulated flask containing warm water at $37^{\circ} \mathrm{C}$ within 30 minutes. In the laboratory, the samples were dissected and histological sections of the right testis, right and left caudal epididymides taken from two bulls in each group. The tissues were fixed in Bouin's fluid. They were processed in an automatic tissue processor, embedded in paraffin wax using the embedding system (Leica EG 1160) and sectioned with microtome at 4 microns. The sections were then stained by Haematoxylin and Eosin method and mounted and examined under a microscope. There was no significant difference between breed and seminiferous tubular diameter (STD) and testicular germinal height (TGEH). The mean STD ranged from $223.00 \pm 28.35$ to $316.00 \pm 37.70 \mu \mathrm{m}$, while the TGEH ranged from $81.60 \pm 10.05$ to $89.80 \pm 4.83 \mu \mathrm{m}$. The mean epididymal tubular diameters (ETD) and epididymal lumen diameters (ELD) had the highest value of $378.00 \pm 10.95$ and $298.20 \pm 26.0489 \mu \mathrm{m}$ in DL and lowest of $373.80 \pm 37.70$ and $278.10 \pm 27.71 \mu \mathrm{m}$ in $\mathrm{RB}$, respectively. The mean epididymal germinal epithelia heights $(\mathrm{EGEH})$ were highest $(61.20 \pm 5.70 \mu \mathrm{m})$ in WF and lowest $(39.80 \pm 0.86 \mu \mathrm{m})$ in RB. The mean sperm head length (SHL), sperm midpiece length (SMPL), sperm tail length (STL) and sperm total length (TL) had the highest values of $5.90 \pm 0.10,8.80 \pm 0.25,24.20 \pm 2.59$ and $38.90 \pm 2.94$ $\mu \mathrm{m}$, respectively in SG. SHL and SMPL were lowest in DL bulls $(5.00 \pm 0.00$ and $6.30 \pm 0.20 \mu \mathrm{m})$, while STL and TL were lowest $(18.90 \pm 0.24$ and $31.30 \pm$
\end{abstract}


$0.85 \mu \mathrm{m})$. The results of this study provide baseline data on the histomorphometry of the testes and epididymides and spermatozoa of some indigenous bulls.

\section{Keywords}

Histomorphometry, Testes, Epididymis, Spermatozoa, Indigenous Bull

\section{Introduction}

Cattle are raised for beef, dairy products, and hides. They are also used as draft animals and in certain sports. Nigeria's livestock resources consist of 14 million cattle, 34 million goats, 22 million sheep, 100 million poultry and 1 million horses and donkeys [1].

The testis is the main organ of the male reproductive system. The testicular parenchyma is composed of seminiferous tubules from which spermatozoa are produced and Leydig cells that produce testosterone which is responsible for male sexuality and secondary male sex characteristics [2] [3] [4].

It is well known that the reproductive performance of the indigenous bull is very poor in comparison to those of different pure breeds [5]. As most of the cattle population of Nigeria is indigenous type and, therefore, various efforts have been made in the recent past in Nigeria to improve the semen quality of indigenous bull through cross-breeding or by upgrading programmes with different pure breeds. To improve the reproductive potential, including expressing heterosis in developing countries, semen from exotic dairy breeds of known genetics is used for breeding local zebu cattle [6]. Although pure exotic breeds are not easily affordable to the majority of farmers and are easily susceptible to trypanosomosis, thereby limiting their use. Therefore, it is imperative that among the indigenous breeds, we should be able to select breeds with more reproductive potential [7].

Great attention to study the reproductive organs has always been reported, particularly those of morphological structure and physiological functions of reproductive organs in many species [8] [9]. Quantitative testicular histology has been used to determine daily sperm production in the boar [10] and shorthorn bull [11]. Though there have been some research reports on bovine testicular measurements [12], biometry of bull testes [5], testicular development and establishment of spermatogenesis in Holstein bulls [13], development of testes in Assam goats [14], comprehensive study on the histomorphological and histochemical features of testes in indigenous bulls in Nigeria is scanty. There is a dearth of information mostly on the indigenous breeds of cattle especially in the area of morphometric studies. Identification of the breed with the largest scrotal circumference is indicative of higher sperm production and increased testicular volume [15]. This study was carried out to provide baseline data on this subject area, which could facilitate an improved breeding programme of indigenous 
Cattle to increase the availability of animal protein for human consumption, especially in West African Communities.

\section{Material and Methods}

\subsection{Sample Collection and Study Location}

Twenty clinically healthy bulls from the Red Bororo (RB), Sokoto Gudali (SG), White Fulani (WF) and Dhali (DL) breeds were randomly selected at the Bodija abattoir, located about two kilometers from the University of Ibadan campus at latitude $\mathrm{N} 07^{\circ} 25^{\prime} 984^{\prime \prime}$ and longitude E $03^{\circ} 54^{\prime} 887^{\prime \prime}$. The study location has an average relative humidity of $80 \%$, an ambient temperature of $34^{\circ} \mathrm{C}$ and a total annual rainfall of 12,000 $\mathrm{mm}$. The selected bulls included 5 each from the Red Bororo (RB), Sokoto Gudali (SG), White Fulani (WF) and Dhali (DL) breeds. Their ages were determined by dentition, while their body weights and scrotal circumferences were taken with a calibrated weight tape and a measuring tape respectively before slaughter. The testicles were harvested from the bulls immediately after slaughter and thereafter placed in a well-insulated flask maintained at $37^{\circ} \mathrm{C}$ and then transported within 30 minutes to the Veterinary Reproduction laboratory of the University of Ibadan for further processing.

\subsection{Testicular, Epididymal and Spermatozoa Histomorphometry}

In the laboratory, the samples were dissected and histological sections of the right testis, right and left caudal epididymides were collected from two bulls in each group and processed. The tissues were fixed in Bouin's fluid. They were processed in an automatic tissue processor. The tissues were then embedded in paraffin wax using the embedding system (Leica EG 1160). They were thereafter sectioned with microtome at 4 microns. The sections were then floated on water using a water bath at $45^{\circ} \mathrm{C}$ and then picked on frosted end slide. The slides were fixed on a hotplate for about thirty minutes. The sections were then stained by Haematoxylin and Eosin method and mounted.

Sperm cells were obtained from linear incisions made on the caudal epididymis and flushed out with physiological saline for microscopic analyses. Photomicrograph of the testes, epididymides, and spermatozoa was taken using the MEM 300 digital eyepiece for microscope and its software fitted on an Olympus microscope as shown in Figures 1-3 respectively.

\subsection{Statistical Analysis}

Data were analyzed using a one-way Analysis of variance (ANOVA). Significance differences between means were separated using Duncan's multiple range tests at a $5 \%$ probability level.

\section{Results and Discussion}

The mean age, body weight and testicular circumference (TC) of indigenous bulls, are shown in Table 1. There was no significant difference between breed 


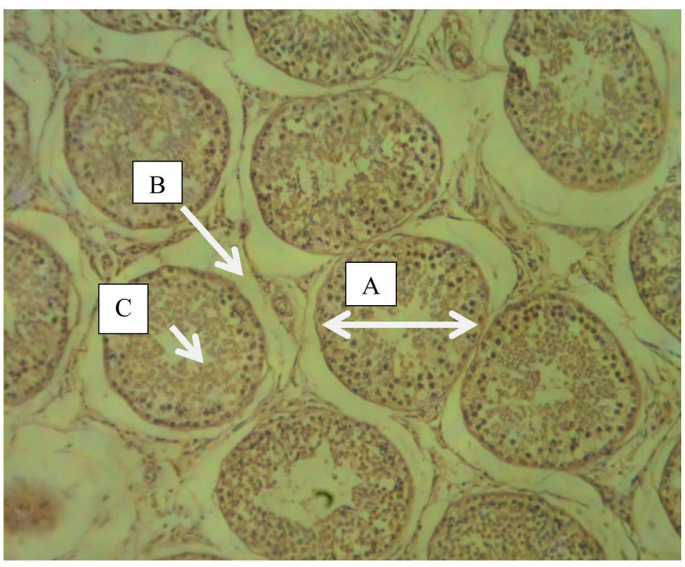

Figure 1. Photomicrograph of DL testis showing seminiferous tubules (transverse section) with $\mathrm{H} \& \mathrm{E}$ stain $40 \times$. A-SeminiferoustTubular diameter; B-Interstitium; C-Lumen.

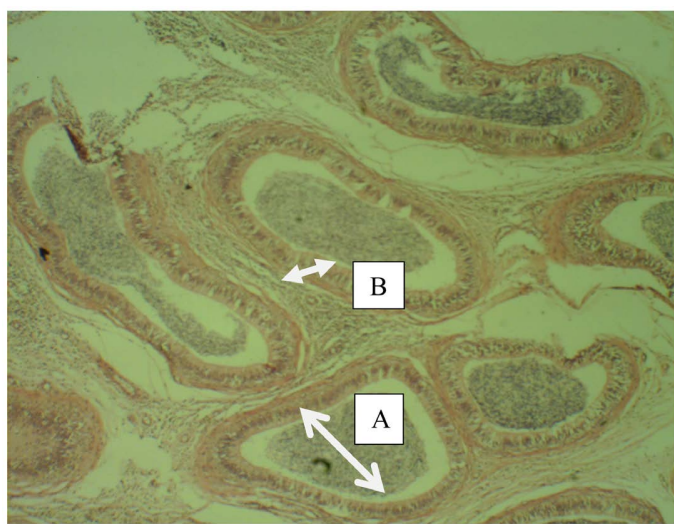

Figure 2. Photomicrograph of DL caudal epididymis (transverse section) with $\mathrm{H} \& \mathrm{E}$ stain $40 \times$. A = Lumen diameter; $\mathrm{B}=$ Germinal epithelium.

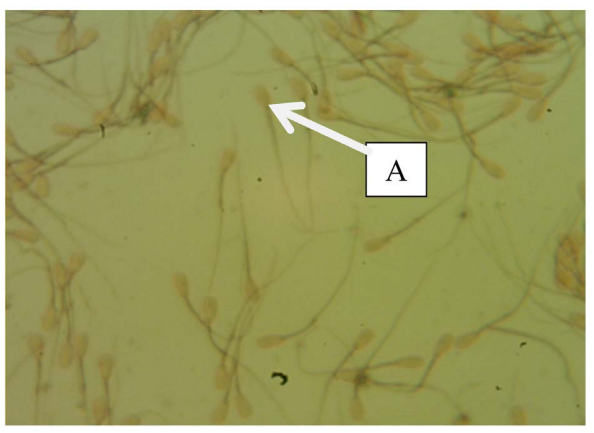

Figure 3. Photomicrograph of smear from LET of WF with black arrow showing a normal spermatozoon with Eosin \& Nigrosin stain 400×. A-A normal sperm cell.

and mean body weight and testicular circumference of bulls. The mean body weight was $603.20 \pm 52.92 \mathrm{Kg}$, while the testicular circumference (TC) ranged from $15.40 \pm 0.24$ to $15.92 \pm 0.62 \mathrm{~cm}$. There was a significant difference between breed and age of bulls. Red Bororo (RB) bulls were the oldest, followed by Sokoto Gudali (SG) and White Fulani (WF) respectively, while the Dhali (DL) was the youngest bulls. 
Table 1. Gross morphological parameters of bulls.

\begin{tabular}{cccc}
\hline Breed & Age (Months) & Body weight $(\mathrm{kg})$ & TC $(\mathrm{cm})$ \\
\hline RB & $50.40 \pm 1.47^{\mathrm{b}}$ & $732.40 \pm 48.93^{\mathrm{a}}$ & $15.50 \pm 0.57^{\mathrm{a}}$ \\
SG & $48.00 \pm 0.00^{\mathrm{ab}}$ & $679.40 \pm 50.54^{\mathrm{a}}$ & $15.92 \pm 0.62^{\mathrm{a}}$ \\
WF & $48.00 \pm 0.00^{\mathrm{ab}}$ & $622.80 \pm 46.65^{\mathrm{a}}$ & $15.40 \pm 0.24^{\mathrm{a}}$ \\
DL & $45.60 \pm 2.40^{\mathrm{a}}$ & $603.20 \pm 52.92^{\mathrm{a}}$ & $15.60 \pm 1.18^{\mathrm{a}}$ \\
\hline
\end{tabular}

Mean of different letters in the same column are significantly different $(\mathrm{p}<0.05)$. RB = Red Bororo, SG $=$ Sokoto Gudali, WF $=$ White Fulani, DL $=$ Dhali, TC $=$ Testicular cir cumference.

The histo-morphological parameters of seminiferous tubules are presented in Table 2. There was no significant difference between breed and seminiferous tubular diameter (STD) and testicular germinal height (TGEH). The mean STD ranged from $223.00 \pm 28.35$ to $316.00 \pm 37.70 \mu \mathrm{m}$, while the TGEH ranged from $81.60 \pm 10.05$ to $89.80 \pm 4.83 \mu \mathrm{m}$.

The mean testicular lumen diameters were significantly different $(\mathrm{p}<0.05)$. The TLD were $105.20 \pm 12.89 \mu \mathrm{m}, 81.60 \pm 18.83 \mu \mathrm{m}, 135.80 \pm 23.66 \mu \mathrm{m}$, and $67.20 \pm 14.25 \mu \mathrm{m}$ respectively with WF having the highest value and DL having the lowest.

The mean values of STD in this study were higher than those reported by Togun, 2009 [16] for zebu cattle in the Oyo state of Nigeria. The reason for this difference may be due to the relatively low body weight of cattle, owned by nomadic herdsmen.

Epididymal parameters are shown in Table 3. There was a significant difference $(p<0.05)$ between breed and epididymal parameters. The mean epididymal tubular diameters (ETD) and epididymal lumen diameters (ELD) had the highest value of $378.00 \pm 10.95$ and $298.20 \pm 26.0489 \mu \mathrm{m}$ in DL and lowest of 373.80 \pm 37.70 and $278.10 \pm 27.71 \mu \mathrm{m}$ in $\mathrm{RB}$, respectively. The mean epididymal germinal epithelia heights (EGEH) were highest $(61.20 \pm 5.70 \mu \mathrm{m})$ in WF and lowest $(39.80 \pm 0.86 \mu \mathrm{m})$ in RB. The ELD was higher in all breeds than the TLD, since the caudal epididymis is the site of spermatozoa storage. This finding agrees with Amann (1981) [13], that epididymis has a wider lumen for the storage of spermatozoa.

Spermatozoa histomorphometry parameters are shown in Table 4 . There were significant differences between breed and these parameters. The mean sperm head length (SHL), sperm midpiece length (SMPL), sperm tail length (STL) and sperm total length had the highest values of $5.90 \pm 0.10,8.80 \pm 0.25,24.20 \pm 2.59$ and $38.90 \pm 2.94 \mu \mathrm{m}$, respectively in SG.

DL bulls recorded the lowest values of $5.00 \pm 0.00$ and $6.30 \pm 0.20 \mu \mathrm{m}$ for SHL and SMPL respectively, while WF had the lowest values of $18.90 \pm 0.24$ and 31.30 $\pm 0.85 \mu \mathrm{m}$, for STL and TL respectively.

The spermatozoa total length of bulls used in this study were found to be smaller than the values $(70-80 \mu \mathrm{m})$ reported by Bhosrekar (1990) [17] for 
Table 2. Histo-morphological parameters of Seminiferous tubules.

\begin{tabular}{cccc}
\hline BREED & STD $(\mu \mathrm{m})$ & TLD $(\mu \mathrm{m})$ & TGEH $(\mu \mathrm{m})$ \\
\hline RB & $284.20 \pm 36.68^{\mathrm{a}}$ & $105.20 \pm 12.89^{\mathrm{ab}}$ & $81.60 \pm 10.05^{\mathrm{a}}$ \\
SG & $316.00 \pm 37.70^{\mathrm{a}}$ & $81.60 \pm 18.83^{\mathrm{a}}$ & $89.80 \pm 4.83^{\mathrm{a}}$ \\
WF & $264.20 \pm 16.91^{\mathrm{a}}$ & $135.80 \pm 23.66^{\mathrm{b}}$ & $82.00 \pm 7.47^{\mathrm{a}}$ \\
DL & $223.00 \pm 28.35^{\mathrm{a}}$ & $67.20 \pm 14.25^{\mathrm{a}}$ & $84.00 \pm 6.15^{\mathrm{a}}$ \\
\hline
\end{tabular}

Mean of different letters in the same column are significantly different $(\mathrm{p}<0.05)$. STD = Seminiferous tubular diameter, TLD $=$ Testicular lumen diameter. TGEH $=$ Testicular germinal epithelium height.

Table 3. Histo-morphological parameters of Epididymis.

\begin{tabular}{cccc}
\hline BREED & ETD $(\mu \mathrm{m})$ & ELD $(\mu \mathrm{m})$ & EGEH $(\mu \mathrm{m})$ \\
\hline RB & $373.80 \pm 37.70^{\mathrm{b}}$ & $278.10 \pm 27.71^{\mathrm{a}}$ & $39.80 \pm 0.86^{\mathrm{a}}$ \\
SG & $212.00 \pm 23.54^{\mathrm{a}}$ & $117.40 \pm 10.14^{\mathrm{b}}$ & $45.60 \pm 3.64^{\mathrm{a}}$ \\
WF & $370.60 \pm 9.18^{\mathrm{b}}$ & $256.40 \pm 10.53^{\mathrm{a}}$ & $61.20 \pm 5.70^{\mathrm{b}}$ \\
DL & $378.00 \pm 10.95^{\mathrm{b}}$ & $298.20 \pm 26.04^{\mathrm{a}}$ & $46.00 \pm 2.92^{\mathrm{a}}$ \\
\hline
\end{tabular}

Means of different letters in the same column are significantly different $(p<0.05)$. ETD = Tubular diameter, ELD = Lumen diameter, EGEH = Germinal epithelium height.

Table 4. Histo-morphological parameters of spermatozoa.

\begin{tabular}{ccccc}
\hline BREED & SHL $(\mu \mathrm{m})$ & SMPL $(\mu \mathrm{m})$ & STL $(\mu \mathrm{m})$ & TL $(\mu \mathrm{m})$ \\
\hline RB & $5.70 \pm 0.20^{\mathrm{b}}$ & $8.10 \pm 0.10^{\mathrm{b}}$ & $20.20 \pm 0.20^{\mathrm{a}}$ & $34.00 \pm 0.50^{\mathrm{a}}$ \\
SG & $5.90 \pm 0.10^{\mathrm{b}}$ & $8.80 \pm 0.25^{\mathrm{b}}$ & $24.20 \pm 2.59^{\mathrm{b}}$ & $38.90 \pm 2.94^{\mathrm{b}}$ \\
WF & $5.60 \pm 0.24^{\mathrm{b}}$ & $6.80 \pm 0.37^{\mathrm{a}}$ & $18.90 \pm 0.24^{\mathrm{a}}$ & $31.30 \pm 0.85^{\mathrm{a}}$ \\
DL & $5.00 \pm 0.00^{\mathrm{a}}$ & $6.30 \pm 0.20^{\mathrm{a}}$ & $20.43 \pm 0.59^{\mathrm{a}}$ & $31.73 \pm 0.79^{\mathrm{a}}$ \\
\hline
\end{tabular}

Means of different letters in the same column are significantly different $(\mathrm{p}<0.05)$. SHL $=$ Spermatozoa head length, SMPL = Spermatozoa midpiece length; STL = Spermatozoa tail length, TL-Spermatozoa total length.

temperate bulls. The spermatozoa midpiece lengths recorded in this study were smaller than the value of $13 \mu \mathrm{m}$ reported by Faulkner and Pineda (1980) [18] for temperate bulls. Sokoto Gudali was not the oldest breed in this study and yet had the longest spermatozoa midpiece of $8.80 \mu \mathrm{m}$. This is at variance with the report by Cummins and Woodall (1985) [19] that age influences spermatozoa midpiece length in bulls.

\section{Conclusion and Recommendation}

The study concluded that testicular parameters were similar among the indigenous breeds, while epididymal and spermatozoa histomorphometry parameters were significantly different. It is recommended that further studies be con- 
ducted to establish an association between these parameters and semen quality.

\section{Conflicts of Interest}

The authors declare that there is no conflict of interest as regards this study and its publication.

\section{Authors Contribution}

Ayodeji Ayotunde Oni and Matthew Olugbenga Oyeyemi designed the study. Ayodeji Ayotunde Oni collected data. Ayodeji Ayotunde Oni, Matthew Olugbenga Oyeyemi, and Joseph Atawalna analyzed data and wrote the draft. All authors read and approved manuscript for submission.

\section{References}

[1] Umar, A.S.S. (2007) Financial Analysis of Small-Scale Beef Fattening Enterprise in Bama Local Government Area of Borno State. An Unpublished M.Sc. Thesis, Department of Agricultural Economics and Rural Sociology, Ahmadu Bello University, Zaria.

[2] Copenhaver, W.M., Kelly, D.E. and Wood, R.L. (1978) Bailey's Text Book of Histology. 17th Edition, Williams and Wilkins Company, Philadelphia, 611-643.

[3] Dellmann, H.D. and Eurell, J.A. (1998) A Textbook of Veterinary Histology. 5th Edition, Williams and Wilkins, Philadelphia, 226-235.

[4] Hafez, R.S.E. (2000) Reproduction in Farm Animals. 7th Edition, Lea and Febiger, Philadelphia, 3-12, 37-43. https://doi.org/10.1002/9781119265306

[5] Gofur, M.R., Khan, M.Z.I., Karim, M.R. and Islam, M.N. (2007) Biometry of Testis of Indigenous Bull (Bos indicus) of Bangladesh in Relation to Body Weight and Scrotal Circumference. Journal of the Bangladesh Society for Agricultural Science and Technology, 4, 205-208.

[6] Rultedge, J.J. (1997). Cattle Breeding System Enabled by in Vitro Embryo Production. Embryo Transfer Newsletter, 15, 14-18.

[7] Hansen, P.J. (2004) Physiological and Cellular Adaptations of Zebu Cattle to Thermal Stress. Animal Reproduction Science, 82-83, 349-360.

https://doi.org/10.1016/j.anireprosci.2004.04.011

[8] Pucek, Z., Jedrzejewski, W., Jedrzejewska, B. and Pucek, M. (1993) Rodent population-Dynamics in a Primeval Deciduous Forest (Bialowieza National Park) in Relation to Weather, Seed Crop, and Predation. Acta Theriologica, 38, 199-232. https://doi.org/10.4098/AT.arch.93-18

[9] Massanyi, P., Jančová, A. and Uhrin, V. (2003) Morphometric Study of Male Reproductive Organs in the Rodent Species Apodemus sylvaticus and Apodemus flavicollis. Bulletin-Veterinary Institute in Pulawy, 47, 133-138.

[10] Kennelly, J.J. and Foote, R.H. (1964) Sampling Boar Testes to Study Spermatogenesis Qualitatively and to Predict Sperm Production. Journal of Animal Science, 23, 160-167. https://doi.org/10.2527/jas1964.231160x

[11] Swienstra, E.E. (1966) Structural Composition of Short Horn Bull Testes and Daily Spermatozoa Production as Determined Quantitative Testicular Histology. Canadian Journal of Animal Science, 46, 107-119.

https://doi.org/10.4141/cjas66-016 
[12] Coulter, G.H. and Foote, R.H. (1979) Bovine Testicular Measurements as Indicators of Reproductive Performance and Their Relationship to Reproductive Traits in Cattle: A Review. Theriogenology, 11, 297-311.

https://doi.org/10.1016/0093-691X(79)90072-4

[13] Crutis, S.K. and Amann, R.P. (1981) Testicular Development and Establishment of Spermatogenesis in Holstein Bulls. Journal of Animal Science, 53, 1645-1657. https://doi.org/10.2527/jas1982.5361645x

[14] Baishya, G., Ahmed, S. and Bhattacharya, M. (1987) Development of Testis in Assam Goat (Capra hircus). Indian Veterinary Journal, 64, 24-28.

[15] Andreussi, P.A.T., Costa, D.S., Faria, F.J.C., Fernandes, C.A.C. and Guimarães, J.D. (2013) Efficiency of the Spermatogenesis in Zebu Bulls (Bos taurus indicus). Anatomia, Histologia, Embryologia, 43, 133-140. https://doi.org/10.1111/ahe.12056

[16] Togun, V.A. (2009) Live Weight Related Changes in the Sperm Production Capacity of White Fulani (Bos indicus) Cattle: Testicular Histomorphometry. Pakistan Journal of Biological Science, 12, 1174-1180. https://doi.org/10.3923/pjbs.2009.1174.1180

[17] Bhosrekar, M.R. (1990) Semen Production and Artificial Insemination. 1st Edition, BAIF Development Foundation, India, 4-205.

[18] Faulkner, L.C. and Pineda, M.H. (1980) Male Reproduction. In: Donald, M.C., Ed., Veterinary Endocrinology and Reproduction, Lea \& Febiger, Philadelphia, 235-273.

[19] Cummins, J.M. and Woodall, P.F. (1985) On Mammalian Sperm Dimensions. Journal of Reproduction and Fertility, 75, 153-175. https://doi.org/10.1530/jrf.0.0750153 